Rapp. Grønlands geol. Unders. 69, 11-16 (1975)

\title{
STRATIGRAPHY AND STRUCTURE OF THE TERTIARY VOLCANIC ROCKS OF THE MARRAIT KITDLÎT AREA, NUGGSSUAQ
}

\author{
Gilroy Henderson
}

\begin{abstract}
Introduction
The volcanic rocks of north-west Nûgssuaq are highly faulted. In order to throw some light on the details of their structure the author undertook detailed mapping in various parts of Nûgssuaq in 1971 and 1972; Marrait kitdlit was one of the areas investigated.

Marrait kitdlit is situated on the south-west side of the Nûgssuaq peninsula 6 $\mathrm{km}$ south-east of the mouth of the Itivdle valley.

\section{Stratigraphy}

The lowest rocks in the area are Cretaceous-Tertiary sediments exposed in the north-western part of the area (fig. 3). North of the delta emerging from the Itivdle valley sandstones and shales of probable Lower Danian age cut by thin irregular dykes are faulted against steeply dipping picrite basalt flows, with dips up to $70^{\circ}$ to the west.

South of the delta sandstones and shales whose age is unknown, but which may be partly Cretaceous, are exposed in four outcrops. In one of these, at the coast, they are overlain by intensely altered pillow breccia, the contact being a fault with NE-SW strike and dip $20^{\circ} \mathrm{SE}$. Fault gouge is present at the contact.

A shallow borehole was drilled in these coastal sediments to a depth of $13.73 \mathrm{~m}$; core recovery was 32 percent. From surface to $7.73 \mathrm{~m}$ the section cored consists of dark grey shale. The section below $7.73 \mathrm{~m}$ consists of shale intruded by sills. The sill material has been examined by $\mathrm{N}$. Hald. In the uppermost part of this section the sills are thin, olive-green and consist of picrite basalt with pseudomorphs after
\end{abstract}




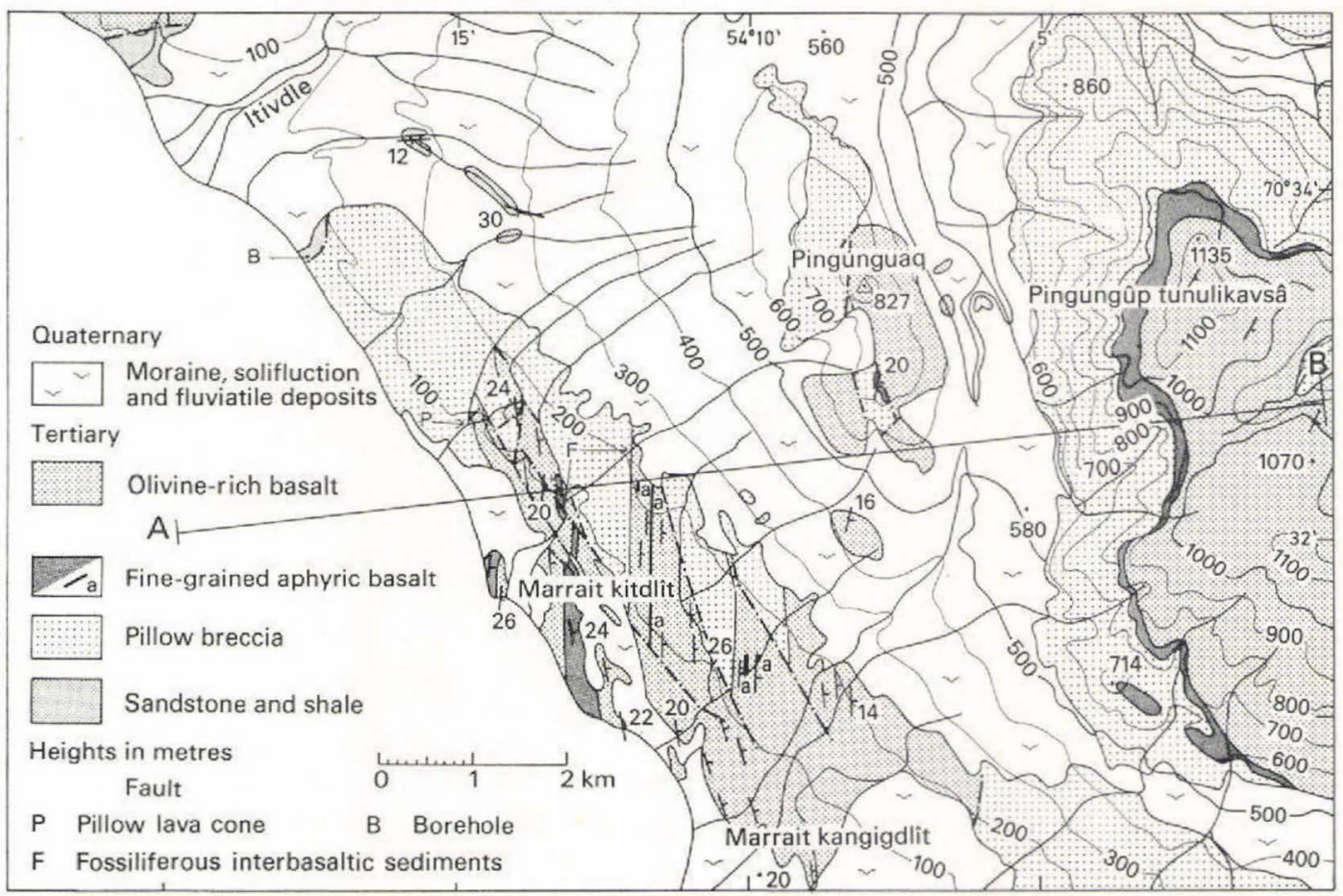

A

B

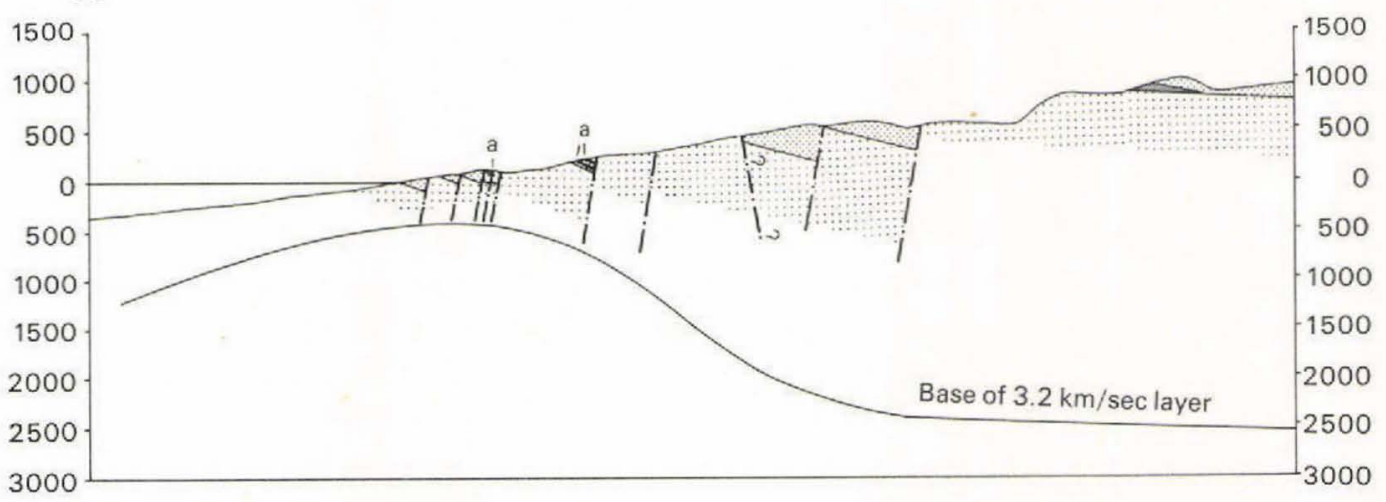

Fig. 3. Geological map and cross-section of the Marrait kitdlit area.

olivine phenocrysts in a devitrified, very fine-grained groundmass. In the deeper part of the section the sills are of grey picrite basalt, less altered, composed of olivine phenocrysts (or pseudomorphs) in a groundmass of plagioclase, augite and opaque minerals. Sulphide mineralisation was found in the olive-green picrite basalts and associated shales. 
Fig. 4. Pillow lava cone in pillow breccia north of Marrait kitdlit.

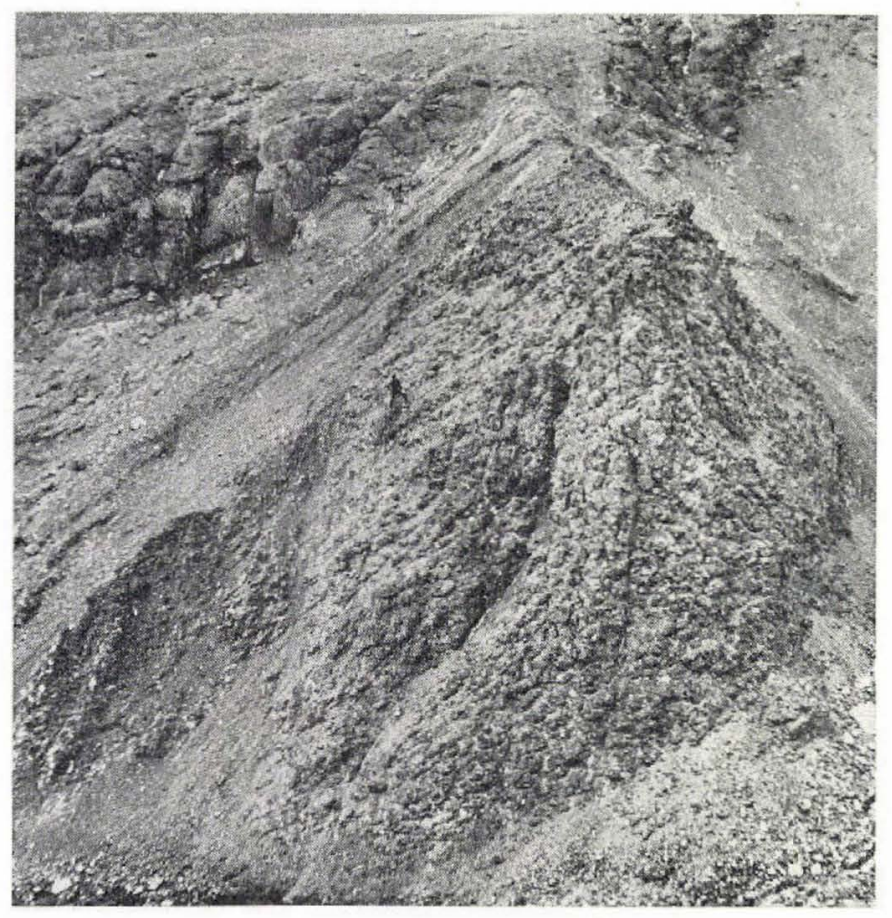

The volcanic rocks near the contact with the shales are so intensely altered that it is difficult to ascertain their original nature. Farther east the volcanic rocks grade into grey pillow breccias on the western side of which are green, altered breccias, which can be seen to be altered pillow breccias.

Because of the intense faulting it is not possible to measure the total thickness of the pillow breccias in the faulted area, but they are at any rate several hundred metres thick. On the north slopes of the mountain Pingúngûp tunulikavsâ, east of the faulted area, they are at least $500 \mathrm{~m}$ thick. Although the rocks are pillow breccias, whole pillows can be seen at various localities. The breccias are generally olivine rich.

Two kilometres north of Marrait kitdlit the pillow breccias contain a conical pillowed, highly altered ultrabasic body $40 \mathrm{~m}$ high (fig. 4). This cone is considered to have built up through the ascent of ultrabasic lava to the sea floor where it consequently formed pillows.

At two localities in the valley upstream from Marrait kitdlit there are intercalations of fossiliferous sediments in the volcanic sequence. The first of these is the well known Marrait kitdlît layer described by Rosenkrantz (1970), Jürgensen \& Mikkelsen (1974) and Binzer \& Karup-Møller (1974). Immediately to the west of the major fault which downthrows subaerial basalts against pillow breccias there is a ridge between two branches of the stream and the sedimentary layer outcrops 


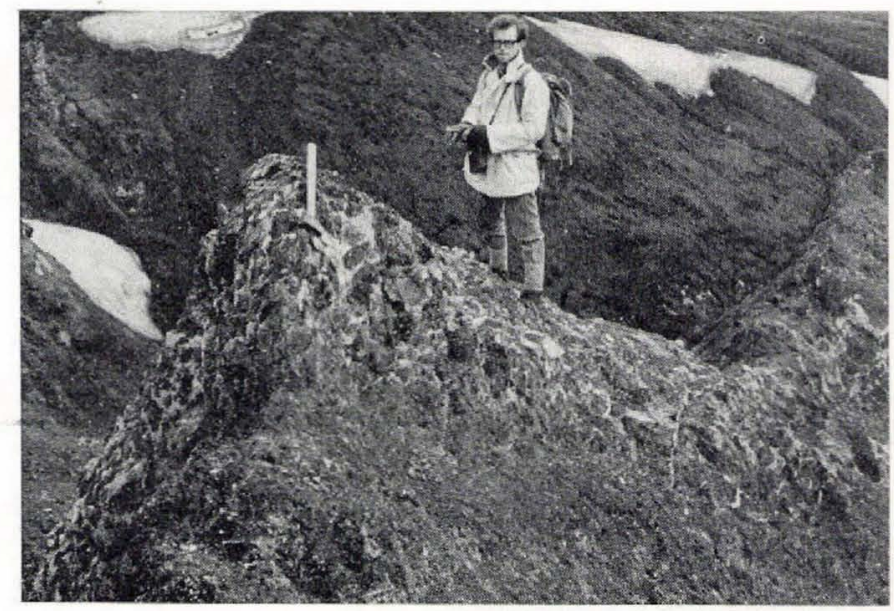

Fig. 5. Basalt conglomerate with fossiliferous limestone matrix, Marrait kitdlit.

on this ridge. Very thin flows of highly vesicular subaerial basalts form most of the west face of the ridge. They are overlain by pillow breccias up to $3 \mathrm{~m}$ thick which pinch out southwards. The Marrait kitdlit layer rests partly on this pillow breccia and partly on the flows. It is a basalt conglomerate (fig. 5) up to $4 \mathrm{~m}$ thick, comprising about 50 percent basalt boulders in a limestone matrix with abundant fossils. It appears to be a very shallow-water, near-shore deposit, the limestone having been deposited in interstices between basalt boulders. The limestone is also found as an infilling in a fracture zone in the underlying flows, which shows that there were open fractures on the sea floor at time of deposition.

A similar fossiliferous zone occurs within pillow breccia about $75 \mathrm{~m}$ west of the boundary with the subaerial flows upstream from the first locality.

The pillow breccias are overlain by subaerial lava flows, which form a very thick sequence east of the area under discussion. At the boundary between the pillow breccias and subaerial flows on the western slopes of Pingúngûp tunulikavsâ there is a spectacular brown tholeitic pillow lava with perfectly preserved pillows of all shapes and sizes, these showing glassy margins (fig. 6).

The subaerial lavas comprise mainly olivine-rich basalt, but at or near the base of the sequence flows of aphyric or nearly aphyric basalt are common. In the stream $2 \mathrm{~km}$ due north of Marrait kangigdlit there are two separate zones of brownish-grey fine-grained basalt. At the coast south of Marrait kitdlit there is one wide zone containing these basalts, the sequence being about $120 \mathrm{~m}$ thick. On the southern peak of the mountain Pingúnguaq pillow breccias are overlain directly by dense, dark grey, nearly aphyric basalt. Since these basalts form a marker zone at or near the base of the subaerial flows this is taken as evidence that the boundary between flows and breccias is not strongly diachronous in this particular area. 


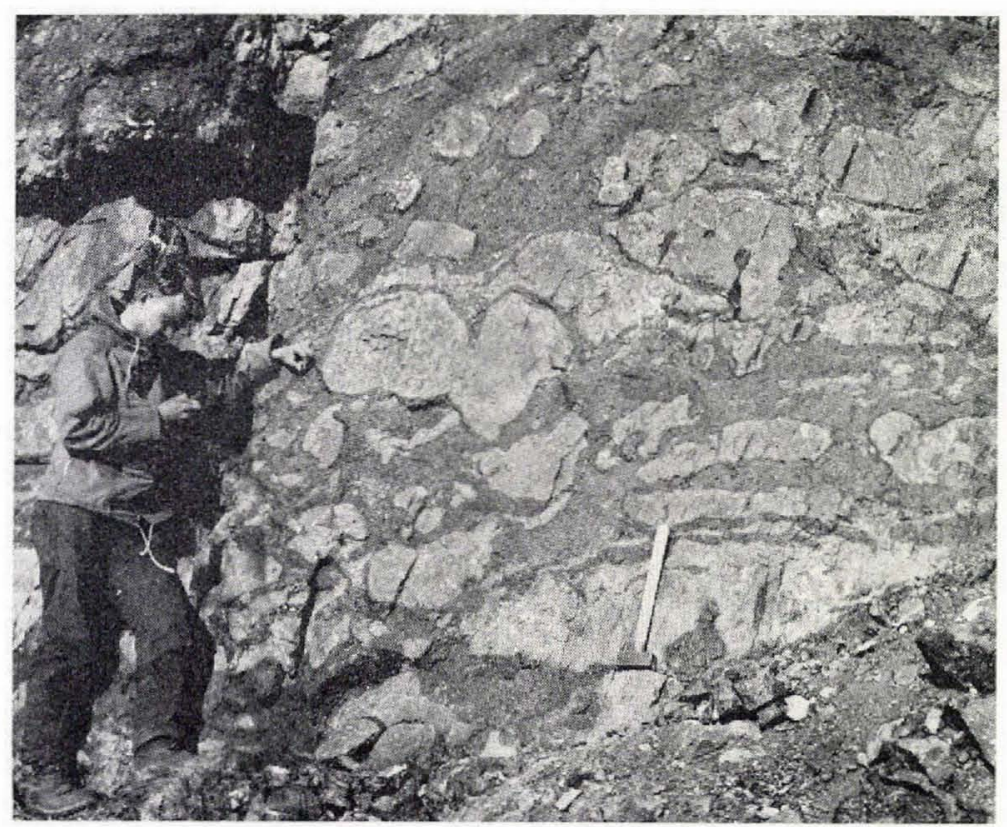

Fig. 6. Pillow lava on west side of Pingúngûp tunulikavsâ.

\section{Structure}

The subaerial flows of Pingúngûp tunulikavsâ form part of an extensive sequence whose updip termination can be traced north-north-east along strike to just south of the Tunorssuaq valley, a distance of about $20 \mathrm{~km}$. The basalts have an average dip of $5^{\circ}$ to the east-south-east. Throughout this stretch of country they are nearly undisturbed by faulting. Farther east the low regional dip decreases until in central Nûgssuaq in the area round Agatdalen the flows are horizontal.

The fault system of the Marrait kitdlit area is initiated with a N-S fault that runs beneath the Quaternary deposits in the depression between Pingúngûp tunulikavsâ and Pingúnguaq. The fault is exposed over a short interval east of Marrait kangigdlit and has a downthrow of at least $750 \mathrm{~m}$ to the west (fig. 3).

Farther west a series of NNW-SSE trending faults produces numerous repetitions of the base of the subaerial lavas. Within the individual fault blocks the strike of the lavas is mainly $\mathrm{N}-\mathrm{S}$ with eastwards dips between $10^{\circ}$ and $30^{\circ}$. The dips are all substantially steeper than the average dip of $5^{\circ}$ to the east-south-east in the area east of the faulted zone.

The fact that the dips of the flows in the faulted zone show such a steepening compared with the dips of the flows to the east could suggest that the fault planes are curved and that rotation of the individual blocks has taken place. In this case the total displacement caused by the faults would be about $1500 \mathrm{~m}$. 
On the other hand, as already pointed out, there is a transition from horizontal lavas in central Nûgssuaq to lavas with $5^{\circ}$ dips just east of the fault zone. If the steeper dips in the fault zone are in general a reflection of originally steeper dips prior to the faulting, the total displacement caused by the faults would be about $2500 \mathrm{~m}$. Whatever the explanation, the total amount of displacement is substantial.

In addition to the system of faults described above, other faults are locally important. In the northern part of Pingúnguaq a system of NNW-SSE to NNESSW trending faults has resulted in substantial easterly downthrow of about $300 \mathrm{~m}$ displacement in all. On this particular mountain there is intense faulting and the exposure is poor, so that it has been difficult to map all the structural details.

A number of cross faults of various trends terminate the wedges of subaerial basalts north of Marrait kitdlitt.

For comparison, the base of the $3.2 \mathrm{~km} / \mathrm{sec}$ layer as determined by seismic refraction surveys undertaken by Elder (this report) has been compiled on the same line of section (fig. 3). This shows an arch with culmination below Marrait kitdlit. If the various faulted segments are restored to their pre-faulting positions, so that the base of the subaerial lavas is continuous, the effect is to steepen the arch considerably. The author has no explanation to offer for the present shape of the seismic marker as compared with the known surface geology.

One naturally wonders why there is such an abrupt westwards change from a very quiet type of structure in the area from Pingúngûp tunulikavsá northwards to the rather violent fault tectonics of the Marrait kitdlitt area, with such large cumulative displacement. The NNW-SSE faults are on trend with a very prominent fracture system in pillow breccias on the south coast of Nûgssuaq. These in turn have the same direction as a prominent dyke swarm and fracture system mapped by A. K. Pedersen on Disko. The N-S fault direction is important in the Itvidle valley fault system to the north of this area. It seems that elements of two important fault systems are present at Marrait kitdlitt, which is thus a key area structurally.

\section{References}

Binzer, K. \& Karup-Mфller, S. 1974: Ferri-sepiolite in hydrothermal calcite-quartz-chalcedony veins on Nagssuaq in West Greenland. Bull. Grønlands geol. Unders. 114 (also Meddr Grønland 201, 5) 16 pp.

Rosenkrantz, A. 1970: Marine Upper Cretaceous and lowermost Tertiary deposits in West Greenland. Meddr dansk geol. Foren. 19, 406-453.

Jürgensen, T. \& Mikkelsen, N. 1974: Coccoliths from volcanic sediments (Danian) in Nûgssuaq, West Greenland. Bull. geol. Soc. Denmark 23, 225-230. 